\title{
Morphological Study of the Eye Bulb of the Hammerhead Shark, Sphyrna lewini (Elasmobranch: Carcharhinidae)
}

\author{
Estudio Morfológico del Bulbo Ocular del Tiburón Martillo, \\ Sphyrna lewini (Elasmobranch: Carcharhinidae)
}

\author{
Muriana, C. B. ${ }^{1}$; Vasconcelos, B. V. ${ }^{2}$; Leandro, R. M. ${ }^{3}$, Malavasi, C. E. ${ }^{3}$; \\ Amorim, A. F. ${ }^{1}$; Rici, R. E. G. ${ }^{3}$; Maria, D. A. ${ }^{4}$; Miglino, M. A. ${ }^{3}$ \& Ferreira, A.O. ${ }^{3}$
}

\begin{abstract}
MURIANA, C. B.; VASCONCELOS, B. V.; LEANDRO, R. M.; MALAVASI, C. E.; AMORIM, A. F.; RICI, R. E. G.; MARIA, D. A.; MIGLINO, M.A. \& FERREIRA, A. O. Morphological study of the eye bulb of the hammerhead shark, Sphyrna lewini (Elasmobranch: Carcharhinidae). Int. J. Morphol., 35(1):287-292, 2017.
\end{abstract}

SUMMARY: The hammerhead sharks shows a head laterally expanded with eyes and nostrils on the edges, which gives the species a hammer appearance. Another strand of studies indicates that the hypothesis of head shape alterations for better adaptions in the sensorial system with the development of structures associated to binocular sight and others sensorial organs. Given the variety of characteristics, the study aim was to describe the anatomical constitution of the hammerhead shark eye bulb. The bulb and its annexes exenteration was performed, and further dissection; the morphological description of the muscle insertions and eye bulb components were based on direct observation and were further photographed and catalogued. The eye bulb fragments and its annexes were histological technical. Between the sclera and the choroid it was possible to observe, by the electronical scanning microscopy, the thin layer called supra-choroid, in this region, spaces often filled by lymphatic vessels allied to a matrix formed by loose conjunctive tissue are found. In the choroid, a layer which is rich in blood vessels, loose conjunctive tissue and collagen fibers, was observed, besides pigmentary cells full of melanin in its interior, which result in its layer's dark color. Ciliary body is a choroid's dilatation; it has the aspect of a thick ring in finger-like shape, pigmented, covering the sclera surface and containing pigmentary cells. The crystalline capsule, which shows an acellular covering that, is hyaline and homogeneous. In the electronical scanning microscopy, it was observed that the capsule is extremely thick especially in the anterior face. The capsule is very elastic, constituted mainly by thin lamellae of collagenous fibers, as illustrated by the electronically scanning microscopy. Anatomic variations related mainly to the position of the eye bulb in the skull, fibrous tunica and lens call the attention and must be related to its habitat.

KEY WORDS: Cartilaginous fish; Chondrichthyes; Vision; Microscopy; Morphology.

\section{INTRODUCTION}

The subclass Elasmobranches has around 1.130 living (Compagno, 1990), they are vertebrate and the majority are at the top of the trophic chain in the aquatic ecosystem, thus, they have a major role in the quality maintenance of the ecosystem they attend. Currently, a few more than 500 of sharks are known, which are practically cosmopolitans in the oceans, from tropical regions to temperate regions; some of them get to attend rivers which are many kilometers within the continent (Compagno; Ebert et al., 2013).

The Family Sphyrnidae, known as hammerhead sharks shows a dimorphism compared to the other species of shark: its head laterally expanded with eyes and nostrils on the edges, which gives the species a hammer appearance. Due to these differences, they are put in a distinct family; morphologic and genetic studies, however, indicate they are a sub taxon of the Carcharhinidae family (Naylor, 1992). Eight species of hammerhead sharks have been described so far; they are animals that attend tropical and temperate areas all around the world (Ebert et al.). They are top predators, adapted to the predation of different species of organisms (Compagno; Ebert et al.).

The shape of these shark heads has been studied for years and different hypothesis have been raised; according to (Nakaya, 1995; Kajiura et al., 2003) the widest head

${ }^{1}$ Fish Institute, Santos, Brazil.

${ }^{2}$ Department of Veterinary Sciences, Institute of Agro Sciences, Federal University of Mato Grosso, Brazil.

${ }^{3}$ School of Veterinary Medicine, University of São Paulo, Department, of Anatomy of Domestic and Wild Animals, Brazil.

${ }^{4}$ Department of Biochemistry and Biophysics, Butantã Institute, São Paulo, Brazil. 
provides more stability and maneuver capacity to the animals. Another strand of studies indicates that the head shape is an adaptation of predation once it would be easier to manipulate and immobilize preys like Myliobatiformes skates and rays, as described by (Chapman \& Gruber, 2002). Also, the hypothesis of head shape alterations for better adaptions in the sensorial system with the development of structures associated to olfaction, expansion of the distribution of Ampullae Lorenzini and binocular sight. (Johnsen \& Teeter, 1985; Kajiura, 2001; Kajiura, 2003; Kajiura et al., 2005; McComb et al., 2009; Gardiner \& Atema, 2010). Given the variety of characteristics, the study aims to describe the anatomical constitution of the hammerhead shark eye bulb.

\section{MATERIAL AND METHOD}

These animals were donated to the collection of Fishing Institute, Santos City, São Paulo State, already fixed in $10 \%$ formaldehyde, for the Anatomy Sector of Domestic and Wild Animals of the Veterinary and Zootechnics of University of São Paulo (FMVZ - USP).

The bulb and its annexes exenteration was performed, and further dissection; the morphological description of the muscle insertions and eye bulb components were based on direct observation and were further photographed by an Olympus C-315 5,1MP digital camera to be catalogued.

During the sample processing to the Light Microscopy (Paraplast Embedding Media - Paraplast Plus, Oxford Lab., USA), the eye bulb fragments and its annexes were dehydrated in growing levels of alcohols concentration (70-100 \%) and further inclusion in paraplast. In the paraplast blocks, $5 \mu \mathrm{m}$ thick cuts were done using the microtome (Leika, RM 2245, Germany). Afterwards, the cuts were put under slides and stained with HE, and photo-documented in the Nikon Eclipse E800 microscope.

In the process of electronic scanning microscopy, the material collected was washed in distilled water and post-fixed in solution of $1 \%$ osmium tetroxide in $0.1 \%$ PBS. Further the samples were washed in $0.10 \%$ PBS solution, and in distilled water. Finally, the material was dehydrated in growing levels of alcohols in concentrations from $50 \%$ to $100 \%$. The samples were dried in critical points apparatus Balzers CPD 020. The specimens were mounted on aluminum stubs which were appropriate for the electronic scanning microscopy, using carbon glue. Right after, they were submitted to a metallic cover (sputting) with gold in the Sputter Coater EMITECH K550 (FMVZ-USP), being analyzed and photographed in electronic scanning microscope LEO 435VP (FMVZ-USP).

\section{RESULTS}

In the species Sphyrna lewini two groups of extrinsic ocular muscles well developed and functional were observed: the oblique and rectus muscles. Through the dorsal view, as represented by Fig. 1, dorsal oblique muscle is clearly evident, it is short in length when compared to the rectus muscles. Its origin occurs in the joint point between the lateral wall of the nasal capsule and the edge of the distal wing of the pre-orbital process. Concerning to its insertion, there is a common point located anterior to the equatorial line in direction to the sclera, of the dorsal and ventral oblique muscle. The dorsal oblique muscle is inserted in the anterior superior portion and the ventral oblique one, in the anterior inferior part.

Four rectus muscles delimit the eye bulb: lateral, medial, dorsal e ventral. Three are clearly evident in a dorsal view as represented by Fig. 1. The rectus muscles are originated in the posterior segment of the orbit and in this point they are fused and individualize themselves according to their approximation of the sclera adhering to the optical pedicle.

Regarding the insertion of the rectus dorsal muscle, it is located beside the point of insertion of the oblique dorsal muscle in the equatorial region of the eye bulb, specifically in the superior medium of the sclera (Fig. 1). The ventral rectus one is inserted next to the ventral oblique,

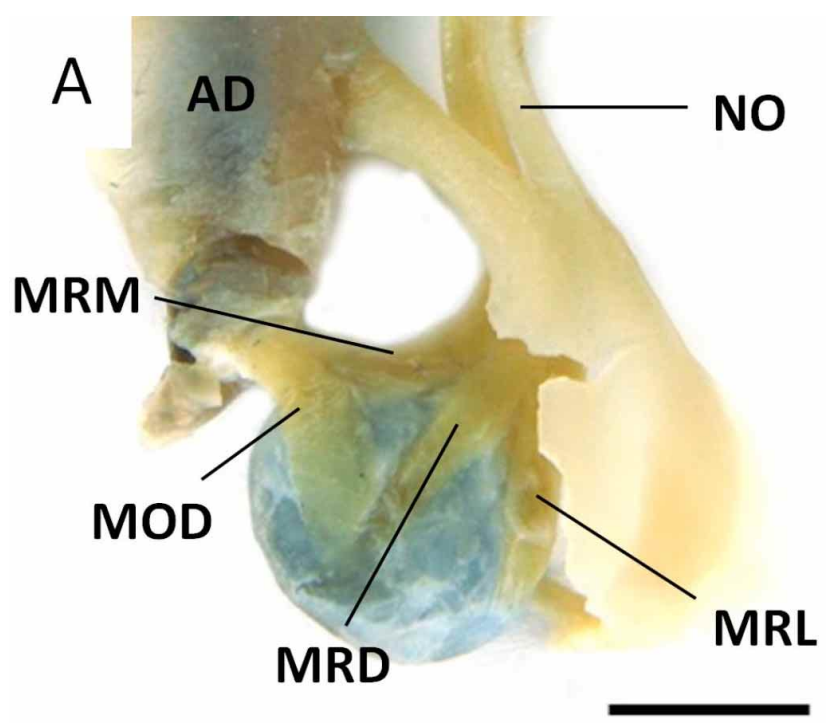

Fig. 1. Pictures of the bulb musculature and the eye bulb. The distal wing of the pre-orbital process (AD), optical nerve (NO) and the muscles: medial rectus muscle (MRM), rectus dorsal (MRD), rectus lateral (MRL) and dorsal oblique (MOD). 

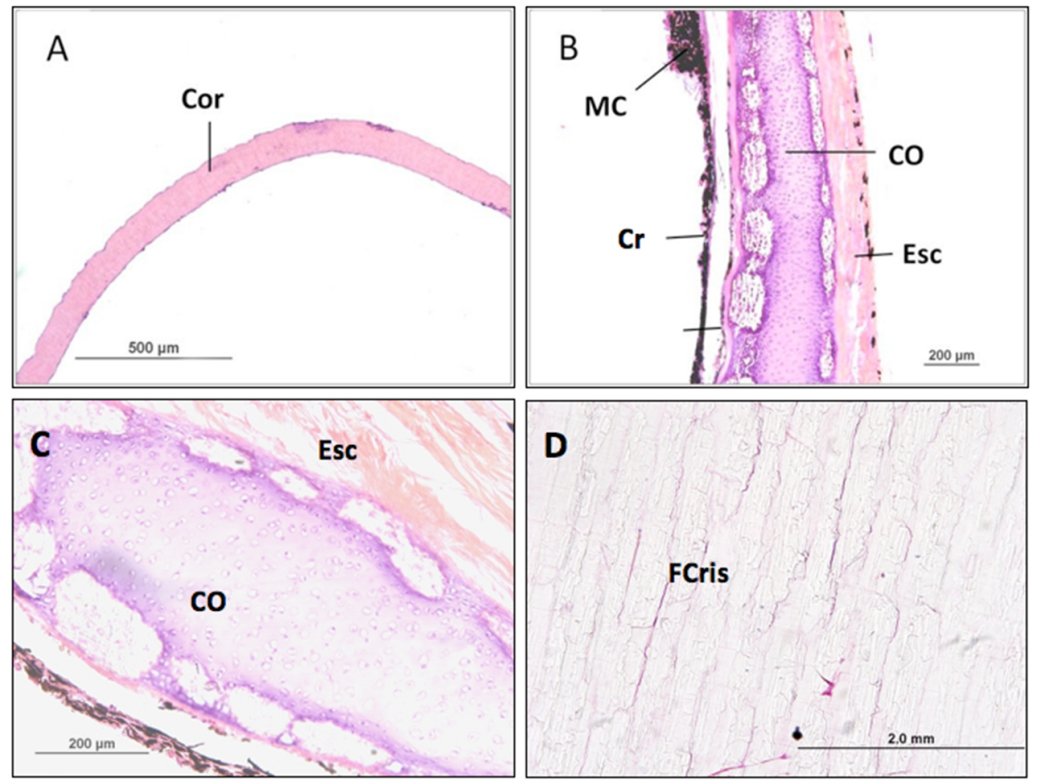

Fig. 2. Photomicrographs of the eye bulb of the Sphyrna lewini. In A, putting the cornea in evidence (Cor) and separately in a close. In B and $\mathrm{C}$, the sclera presence (Esc), optic cartilage (CO), choroid (Cr). HE staining. A, 4x e B, 10x. D. Crystalline Fibers.
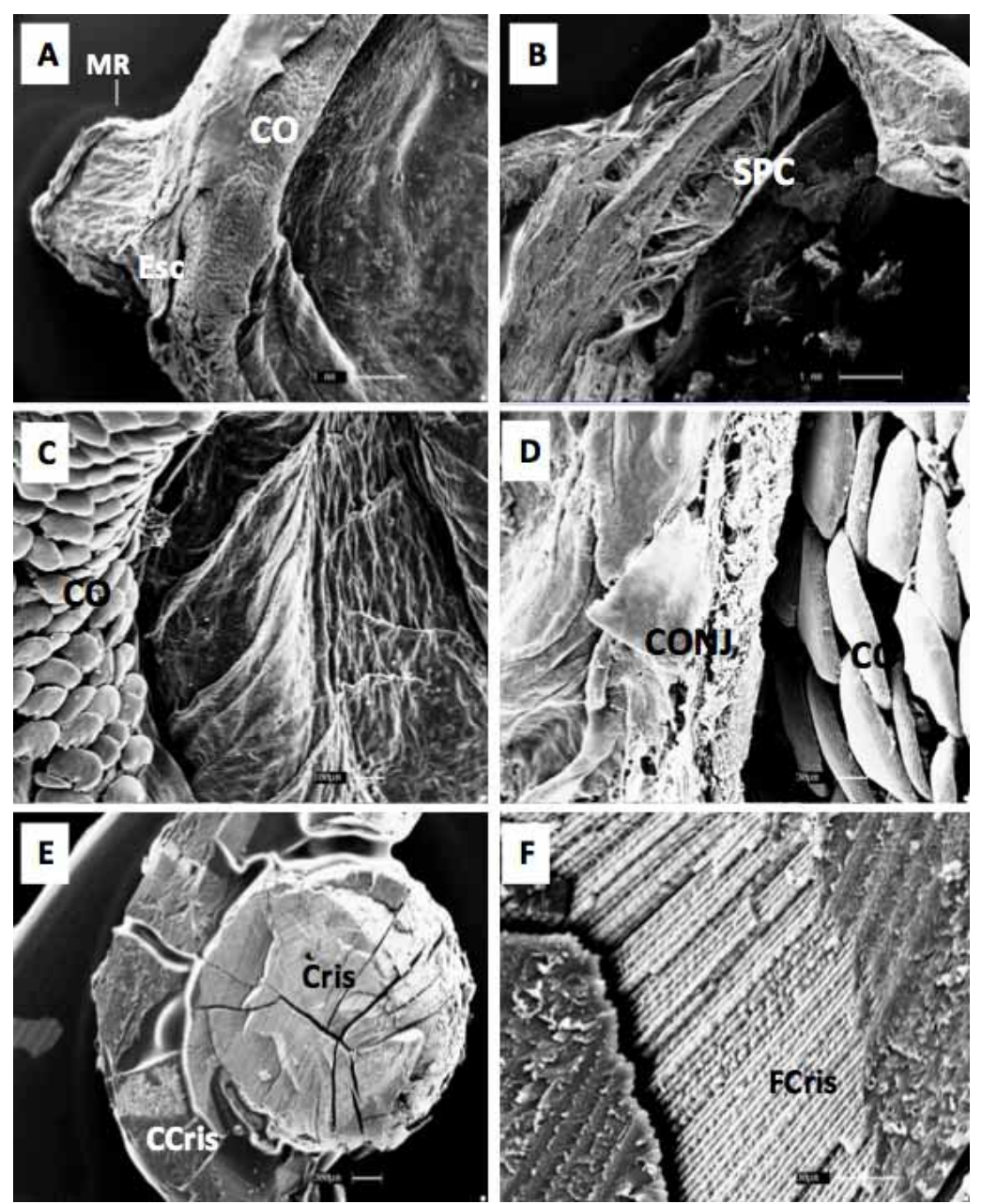

in the inferior medium part. The medial rectus muscle has it insertion in the medium anterior region of the capsule, getting fixed between the oblique ones, while the lateral rectus one emits muscular fibers, being inserted in the medium posterior region of the sclera and optical cartilage (Fig. 3A).

The eye bulb of Sphyrna lewini is small proportionally to its body, has three thin tunica which are in narrow apposition, making a laminated sheet that surrounds the center partially liquid and gelatinous. The three tunica are: external fibrous tunica which shapes and protects the eye bulb. It is complete and divided in cornea and sclera. Tunica media (incomplete) consists of three structures, named iris, ciliary body and internal nervous tunica.

The lateral portion of the fibrous tunica is modified and has as a characteristic a transparent structure called cornea (Fig. 2A). The cornea is formed by an anterior stratified squamous non keratinized epithelium. The basal layer of the epithelium cells is separated from the Bowman layer by a thin basal layer. The stroma corresponds to the biggest part of the cornea and is constituted by collagen fibers organized in parallel bunches in multiple layers. The cornea posterior epithelium is simple squamous type.

The biggest part of the fibrous tunica is the sclera which is formed by conjunctive tissue, rich in collagen fibers that assume direction parallel to the eye bulb surface according to (Figs. $2 \mathrm{~B}$ and $\mathrm{C}$ ). In Figure 2B it is possible to observe that in the peripheral sclera layer there are pigmentary cells, which gives a characteristic grayish color to this species bulb. Externally covering the sclera, there is a bulb conjunctive (Fig. 3D). In a deeper sclera layer of Sphyrna lewini optical cartilage is found and it is formed by hyaline

Fig. 3. Electro micrographs of external portion transmission of the eye bulb of Sphyrna lewini. In $\mathrm{A}$ and $\mathrm{B}$, it is possible to notice the lateral rectus muscle (MR), sclera (Esc), optic cartilage (CO), SPC (supra choroid), Conj (conjunctive). In $\mathrm{C}$ and D optic cartilage (CO), conjunctive (conj).In E and F, the crystalline capsule (CCris), Lens (Cris) and lens fibers (FCris) are observed. 
cartilage that corresponds to the biggest sclera layer (Figs. $2 \mathrm{~B}, \mathrm{C}$ and $3 \mathrm{~A}, \mathrm{C})$. Externally covering the sclera, there is a bulb conjunctive (Fig. 3D).

The pigmented structure, visible through the cornea is the iris, first part of the vascular tunica and is located between the cornea and the lens, in Sphyrna lewini, it shows a horizontal hole, the pupil, in its core, through where the light enters the eye.

Between the sclera and the choroid it was possible to observe, by the electronical scanning microscopy, the thin layer called supra-choroid (Fig. 3B). In this region, spaces often filled by lymphatic vessels allied to a matrix formed by loose conjunctive tissue are found.

In the choroid, a layer which is rich in blood vessels, loose conjunctive tissue and collagen fibers, was observed, besides pigmentary cells full of melanin in its interior, which result in its layer's dark color (Fig. 2B, C). Ciliary body is a choroid's dilatation, it has the aspect of a thick ring in fingerlike shape, pigmented, covering the sclera surface and containing pigmentary cells.

The lens is large and spherical. The fibers of the lens show thin and long prismatic form, arranged longitudinally. These cells are anuclear, its cytoplasm has few organelles. The figure $2 \mathrm{D}$ shows the crystalline capsule, which shows an acellular covering that is hyaline and homogeneous. In the electronically scanning microscopy, it was observed that the capsule is extremely thick especially in the anterior face (Fig. 3E). The capsule is very elastic, constituted mainly by thin lamellae of collagenous fibers, as illustrated by the electronically scanning microscopy (Fig. 3F).

\section{DISCUSSION}

The eyes of most elasmobranches are prominent and put laterally in the head, having binocular visual range. An exception can be the Sphyrnidae hammerhead sharks, whose visual range apparently do not overlap each other, limiting the binocular sight, even though, they reach a wide 360 degrees visual range due to the sinusoidal swimming pattern (Hueter, 2004).

The size of the elasmobranch eyes is proportionally small compared to the size of its body. The bulb is not totally fixed in the orbit, so in the medial face of this cavity a cartilaginous structure named optical pedicle is found, whose function is to sustain the sclera and fix the bulb in the skull.
This structure follows paralleled the junction of the straight muscles (Hueter).

The extra-ocular muscles are well developed, the origin and insertion of the rectus and oblique muscles are similar to other vertebrates, which is similarly observed by (Lima et al., 1997). Descriptive studies of the extra-ocular musculature of the Sphyrna lewini are scarce. There are reports which describe the topography of these muscles in the sharks (Squalus Linnaeus, 1758; Etmopterus Rafinesque, 1810, Squatina Dumeril, 1806, Scyliorhinus Blainville, 1816 e Pristiurus Bonaparte, 1834") relating them to their respective way of life (Lima et al.).

The external layer to the fibrous tunica comprehends a thick sclera, composed mainly by dense conjunctive tissue in its periphery and by hyaline cartilage in its medium portion. In the Sphyrna lewini this layer provides the form and protection of the eye bulb as well as helping with external protection against physical environmental aggressions, since these animals, besides being far from the coast, live in huge depths, which reach 275 meter in high atmospheric pressure (Paragó, 1997).

The cornea is slightly transparent and curvaceous; it is structurally similar to all vertebrate and other elasmobranches composing the interface between the eye and the environment (Collin \& Collin, 1998; Hueter). It is made by six layers in the anterior posterior way. The first layer is the epithelium, which, in this species can reach 50 $\%$ of the total thickness of the cornea when compared to the human epithelium that corresponds to only $10 \%$ of the total thickness (Collin \& Collin). In this study, the epithelial layer thickness was not evaluated. This thickness difference is believed to be related to the close contact of this layer with the sea water. The basal layer of the epithelial cells is separated from the Bowman layer by a thin basal layer similar to the man's and other vertebrates (Collin \& Collin; Hueter). The fourth layer, known as stroma is an average $0.07 \mathrm{~mm}$ thick and contains 25 lamellae. The lamellae dense collagen fibers are embedded in a matrix and paralleled organized. The last layer is named Descemet membrane; not usually found in teleosteo fish, it is a monolayer of mesothelial cells (endothelium) in contact with aqueous humor (Harding et al., 1974; Collin \& Collin; Hueter).

The cornea has as a feature the transparency in demanding chemical environments due to its mechanism of deturgescence and organization of collagenous fibers as well as presence of sutures found in the stromal layer (Tolpin et al., 1969). Differently from other vertebrate including the mammals, the corneous endothelium is not part of this transparency mechanism (Hueter). 
In humans, the cornea is the main element of refraction of the eye and is responsible for $75 \%$ of normal refraction (Collin \& Collin; Hueter). However, in aquatic animals, the cornea refraction role is severely reduced because the sea water and the cornea have very similar refractive index. Consequently, the biggest part of the refraction occurs in the big lens that has ellipsoidal shape free from optical aberration. This optical adjustment may be associated to the thick layer of the lens capsule. This feature provides high elasticity maximizing the accommodation process.

Some elasmobranch's lenses may contain yellowish pigments which are enzymatically formed by the products of tryptophan's oxidation, similar to lens' pigments found in many teleostians and animals with diurnal terrestrial habits. These pigments can filter the ultraviolet (UV) ionizing radiation, minimizing chromatic aberration, besides protecting the retina from the UV damages in shallow waters (Hueter)

According to Zigman (1990) yellowish pigments in lenses were found in fish with coastal and surface habitation and the main listed species are Carcharhinus plumbeus, C. obscurus, Galeocerdo Cuvier. Pigments in the analyzed Sphyrna lewini were not found, and this may be directly associated to its habitats and because they live in great depths. Nelson et al. (2003), reported that the protective mechanism of UV radiation was related to the corneas.

Media tunica (incomplete) consists of three structures named iris, ciliary body and choroid, whose function is to provide nurture of the retina and deeper portions of the sclera, besides regulating the lens accommodation. Opposite to the teleostians, the Sphyrna lewini have dynamic iris with hori- zontal cut, which can increase the pupil size with little light or decrease it under daylight (Hueter).

The posterior segment of the vascular tunica is the choroid which is located below the sclera. In the elasmobranchs the uvea is the only vascularized tissue of the adult eye (Hueter). The highest concentration of blood vessels is found in the deepest layer, named choreocapilar. This location of vessels favors the nurture to the retina. Between the cornea and choroid spaces filled with lymphatic vessels known as supra choroid are found (Hueter).

The pattern of the Sphyrna lewini eye bulb development and its annexes obey a typical pattern when compared to other vertebrates. Anatomic variations related mainly to the position of the eye bulb in the skull, fibrous tunica and lens call the attention and must be related to its habitat. Morphological studies of the sensorial system of these animals are highly important in order to comprehend how these animals behave in an environment when under high biochemical demand and atmospheric pressure.

\section{CONCLUSION}

The pattern of the Sphyrna lewini eye bulb development and its annexes obey a typical pattern when compared to other vertebrates. Anatomic variations related mainly to the position of the eye bulb in the skull, fibrous tunica and lens call the attention and must be related to its habitat. Morphological studies of the sensorial system of these animals are highly important in order to comprehend how these animals behave in an environment when under high biochemical demand and atmospheric pressure.

MURIANA, C. B.; VASCONCELOS, B. V.; LEANDRO, R. M.; MALAVASI, C. E.; AMORIM, A. F.; RICI, R. E. G.; MARIA, D. A.; MIGLINO, M. A. \& FERREIRA, A. O. Estudio morfológico del bulbo ocular del tiburón martillo, Sphyrna lewini (Elasmobranch: Carcharhinidae). Int. J. Morphol., 35(1):287-292, 2017.

RESUMEN: El tiburón martillo tiene la cabeza lateralmente expandida con los ojos y la nariz en sus márgenes. Estudios indican que alteraciones de la forma de la cabeza de estos animales son adaptaciones que mejoran el desarrollo del sistema sensorial y estructuras asociadas a la visión binocular y otros órganos sensoriales. Dada la variedad de características, el objetivo del estudio fue describir la constitución anatómica del bulbo ocular. Se disecó el bulbo ocular junto a sus anexos. La descripción morfológica de las inserciones musculares y componentes del bulbo ocular se basaron en la observación directa, siendo éstas fotografiadas y catalogadas. Entre la esclera y la coroides se observó através de microscopía electrónica de barrido, una delgada capa supra-coroides, y vasos linfáticos junto a la matriz formada por tejidos conectivos. La coroides, era abundante en vasos sanguíneos y fibras de tejido conectivo. Se observaron escasas células pigmentarias llenas de melanina, lo que se asemeja a un anillo en forma de dedo, de manera que cubren la superficie de la esclera y células que contienen pigmentos. En la cápsula del lente, fue posible observar un recubrimiento celular, hialino y homogéneo. En la microscopía electrónica de barrido, se observó una cápsula muy gruesa, principalmente en la región frontal. La cápsula elástica,estaba constituida por láminas delgadas, principalmente, por fibras de colágeno. Se concluyó que el bulbo ocular de estos animales posee variaciones anatómicas relacionadas, principalmente, con la posición del bulbo ocular en el cráneo, túnica fibrosa y lente, lo que puede estar directamente relacionado con su hábitat.

PALABRAS CLAVE: Pez cartilaginoso; Chondrichthyes; Visión; Microscopía; Morfología. 
MURIANA, C. B.; VASCONCELOS, B. V.; LEANDRO, R. M.; MALAVASI, C. E.; AMORIM, A. F.; RICI, R. E. G.; MARIA, D. A.; MIGLINO, M. A. \& FERREIRA, A. O. Morphological study of the eye bulb of the hammerhead shark, Sphyrna lewini (Elasmobranch: Carcharhinidae). Int. J. Morphol., 35(1):287-292, 2017.

\section{REFERENCES}

Chapman, D. D. \& Gruber, S. H. A further observation of the prey-handling behavior of the great hammerhead shark, Sphyrna mokarran: Predation upon the spotted eagle ray, Aetobatus narinari. Bull. Mar. Sci., 70(3):947-52, 2002.

Collin, S. P. \& Collin, H. B. A comparative study of the corneal endothelium in vertebrates. Clin. Exp. Optom., 81(6):245-54, 1998.

Compagno, L. J. V. Alternative Life-History Styles of Cartilaginous Fishes in Time and Space. In: Noakes, D. L. G. (Ed.). Developments in Environmental Biology of Fishes. New York, Springer, 1990. pp.3375

Ebert, D. A.; Fowler, S. L.; Compagno, L. J. V. \& Dando, M. Sharks of the World. A Fully Illustrated Guide. Plymouth, Wild Nature Press, 2013.

Gardiner, J. M. \& Atema, J. The function of bilateral odor arrival time differences in olfactory orientation of sharks. Curr. Biol., 20(13):1187$91,2010$.

Harding, C. V.; Bagchi, M.; Weinsieder, A. \& Peters, V. A comparative study of corneal epithelial cell surfaces utilizing the scanning electron microscope. Invest. Ophthalmol., 13(12):906-12, 1974.

Hueter, R. E.; Mann, D. A.; Maruska, K. P.; Sisneros, J. A. \& Demski, L. S. Sensory Biology of Elasmobranchs. In: Carrier, J. C.; Musick, J. A. \& Heithaus, M. R. Biology of Sharks and Their Relatives. Boca Raton, CRC Press, 2004. pp.326-31

Johnsen, P. B. \& Teeter, J. H. Behavioral responses of bonnethead sharks (Sphyrna tiburo) to controlled olfactory stimulation. Mar. Behav. Physiol., 11(4):283-91,1985.

Kajiura, S. M. Head morphology and electrosensory pore distribution of carcharhinid and sphyrnid sharks. Environ. Biol. Fish., 61(2):125-33, 2001.

Kajiura, S. M. Electroreception in neonatal bonnethead sharks, Sphyrna tiburo. Mar. Biol., 143(3):603-11, 2003.

Kajiura, S. M.; Forni, J. B. \& Summers, A. P. Maneuvering in juvenile carcharhinid and sphyrnid sharks: the role of the hammerhead shark cephalofoil. Zool., 106:19-28, 2003.

Kajiura, S. M.; Forni, J. B. \& Summers, A. P. Olfactory morphology of carcharhinid and sphyrnid sharks: does the cephalofoil confer a sensory advantage? J. Morphol., 264(3):253-63, 2005.

Lima, M. da C.; Gomes, U. L.; de Souza-Lima, W. \& Paragó, C. Estudo anatômico comparativo da região cefálica pré-branquial de Sphyrna lewini (Griffith \& Smith) e Rhizoprionodon lalandii (Valenciennes) (Elasmobranchii, Carcharhiniformes) relacionados com a presença do cefalofólio em Sphyrna Rafinesque. Rev. Bras. Zool., 14(2):347-70, 1997.

McComb, D. M.; Tricas, T. C. \& Kajiura, S. M. Enhanced visual fields in hammerhead sharks. J. Exp. Biol., 212(Pt. 24):4010-8, 2009.

Nakaya, K. Hydrodynamic function of the head in the hammerhead sharks (Elasmobranchii: Sphyrnidae). Copeia, 2(3):330-6, 1995.

Naylor, G. J. P. The phylogenetic relationships among requiem and hammerhead sharks: Inferring phylogeny when thousands of equally most parsimonious trees result. Cladistics, 8(4):295-318, 1992.

Nelson, P. A.; Kajiura, S. M. \& Losey, G. S. Exposure to solar radiation may increase ocular UV-filtering in the juvenile scalloped hammerhead shark, Sphyrna lewini. Mar. Biol., 142:53-6, 2003.

Paragó, C. Estudo anatômico comparativo da região cefálica pré-branquial de Shyrna lewini (Griffith \& Smith) relacionados com a presença do cefalofólio em Shyrna rafinesque. Rev. Bras. Zool., 14(2):347-70, 1997.

Tolpin, W. D.; Klyce, S. D. \& Dohlman, C. H. Swelling properties of dogfish cornea. Exp. Eye Res., 8(4):429-37, 1969.

Zigman, S. Comparative biochemistry and biophysics of elasmobranch lenses. J. Exp. Zool. Part A Ecol. Genet. Physiol., 256 (Suppl. 5):29-40, 1990.

\author{
Corresponding author: \\ Dr. Rafael Magdanelo Leandro \\ Av. Prof. Dr. Orlando Marques de Paiva, 87 \\ Setor Anatomia. Dept. Cirurgia \\ Faculdade de Medicina Veterinária e Zootecnia \\ Universidade de São Paulo \\ ZIP 05508-270 \\ São Paulo \\ BRASIL
}

Email: rafaelmagdanelo@usp.br

Received: 12-09-2016

Accepted: 22-12-2016 